\title{
Assessment of Metal Accumulation in the Vegetables and Associated Health Risk in the Upper-Most Ganga-Yamuna Doab Region, India
}

\author{
Vivek Kumar Gaurav, Dushyant Kumar, Chhaya Sharma* \\ Environmental Research Laboratory, Department of Paper Technology, Indian Institute of Technology Roorkee, \\ Roorkee, India \\ Email: gaurav.vivek08@gmail.com, dkumar23evs@gmail.com, *chhaya1964@rediffmail.com
}

How to cite this paper: Gaurav, V.K., Kumar, D. and Sharma, C. (2018) Assessment of Metal Accumulation in the Vegetables and Associated Health Risk in the Upper-Most Ganga-Yamuna Doab Region, India. American Journal of Plant Sciences, 9, 2347-2358.

https://doi.org/10.4236/ajps.2018.912170

Received: September 29, 2018

Accepted: November 4, 2018

Published: November 7, 2018

Copyright (c) 2018 by authors and Scientific Research Publishing Inc. This work is licensed under the Creative Commons Attribution International License (CC BY 4.0).

http://creativecommons.org/licenses/by/4.0/

(c) $\underset{\mathrm{EY}}{\mathrm{C}}$ Open Access

\begin{abstract}
The present study indicates the status of metal contamination in the vegetables/crops grown in the upper most Ganga-Yamuna doab region of India and associated health risk. Commonly grown vegetables and crops were sampled and analyzed for the metal contamination. Maximum concentration $(\mathrm{mg} / \mathrm{kg})$ of $\mathrm{Cd}$ and $\mathrm{Cr}$, was observed in Radish (7.6) and Cabbage (56.24) respectively, whereas maximum concentration of $\mathrm{Pb}, \mathrm{Ni}$ and $\mathrm{Zn}$ was observed in the edible parts of Mustard plant (95.4, 58.6, 756.43 respectively). Bio-concentration factor (BCF) value indicated the transfer level of metal from soil to crop; indicated high transfer value of $\mathrm{Cd}$ in Radish followed by cabbage and spinach. Considerably high BCF value was observed in the Mustard (8.13), Cabbage (4.18) and radish (3.07) for Zn contamination. Estimated daily intake (EDI) and Hazard quotient (HQ) or Non-carcinogenic health risk was calculated using the USEPA method. The result revealed that the metal intake and associated health risk were considerably high in the children population in comparison to the adult population.
\end{abstract}

\section{Keywords}

Heavy Metal, Bio-Concentration Factor, Estimated Daily Intake, Health Risk, Hazard Quotient

\section{Introduction}

The toxicity, ubiquitous nature, and persistence characteristics of heavy metal have raised considerable apprehension globally [1] [2]. Heavy metal contamination in soil deteriorates overall soil quality, productivity and water quality 
through percolation. Heavy metal contamination in agricultural soils is a crucial issue as it can pose long-term environmental problems [3]. Transfer of metals from soil-to-crop is one of the major sources of metal exposure to the human. Unmanaged disposal of waste, runoffs, landfills along with rapid industrialization have severely enriched the soil with metals [4] [5]. Moreover, excessive use of chemical based pesticides, fertilizers and manures in order to counter the demand of food supply has triggered excessive accumulation of metals in the soil. Vegetables grown in such soil accumulate high concentration of toxic metals. Consumption of metal accumulated vegetables/crops may lead to severe health hazards. Due to limited availability of fresh water, use of industrial wastewater for irrigation is a common practice in India. Wastewater contains toxic metals and long-term wastewater irrigation results in accumulation of substantially high concentration of heavy metals. Atmospheric deposition has now been identified as one of the principal sources of heavy metal contamination to crops and vegetables grown in urban and industrial areas [6].

In the present study Saharanpur which lies in the most uppermost part of Doab land which stretches between the river Ganges and Yamuna, India has been taken into the consideration. Primarily Saharanpur is an agricultural district but also comprises of many medium and small scale industries including some highly water intensive large scale industries like Paper Industry, Sugar mill and distilleries [7]. Unmanaged disposal of industrial wastes, long-term wastewater irrigation practices along with other anthropogenic activities have severely affected the soil quality of the study area. This study aims at determining the level of metal contamination in the soil and vegetables growing in the metal contaminated areas, bio-concentration factor or transfer factor, and the health risk associated with the level of metal exposure to the adult and children population.

\section{Material Method}

\subsection{Sampling and Analytical Analysis}

The study area is located in the Saharanpur district $\left(29.8361^{\circ} \mathrm{N}, 77.4702^{\circ} \mathrm{E}\right)$ which is located in the uppermost Ganga-Yamuna doab region (Figure 1). The soil samples were collected from three different areas of Saharanpur district, designated as industrial areas by Ministry of Micro, Small \& Medium Enterprises, Govt. of India [7]. The top-soil $(0-15 \mathrm{~cm})$ were procured randomly from thirty sampling sites from three industrial areas (Pilakhni, Delhi Road and Railway Road) of Saharanpur city. Samples were zipped packed in polyethylene bag, transferred to the laboratory within three hours from sampling and stored at $4^{\circ} \mathrm{C}$ till complete analysis. Before analytical step samples were dried $\left(\right.$ at $\left.50^{\circ} \mathrm{C}\right)$, pulverized and sieved with 70-mesh plastic sieve [8]. The heavy metal was analyzed by digesting the soil samples using USEPA 3052 method [9] in the microwave oven (MarsXpress). Digested transparent solution was cooled, filtered through Whatman no. 42 filter paper and diluted up to $50 \mathrm{~mL}$ with $1 \%$ nitric acid. The 


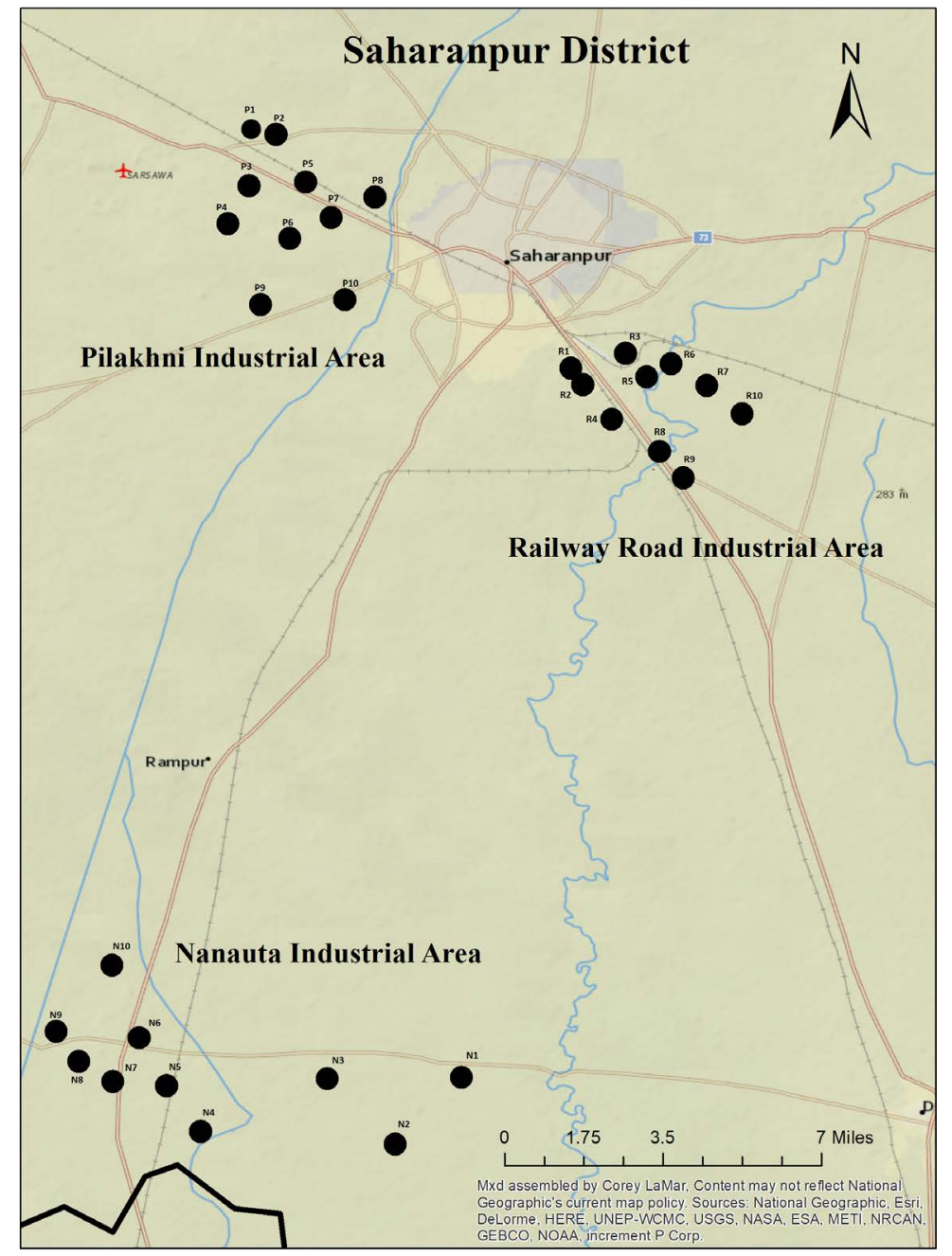

Figure 1. Map showing sampling sites in the study area.

metal concentration in filtrate of digested soil samples were analyzed by ICP-OES.

The edible part of plant samples Spinach (Spinacia oleracea), mustard (Brassica nigra), cabbage (Brassica oleracea), radish (Raphanus sativus), carrot (Daucus carota), sugarcane (Saccharum officinarum), rice grain (Oryza sativa), tomato (Solanum lycopersicum) were collected and washed and dried at $70^{\circ} \mathrm{C}$ $80^{\circ} \mathrm{C}$ for $24 \mathrm{~h}$ to a constant weight. Dried samples were crushed and powdered for homogenization of the sample. Powdered plant samples were digested with concentrated $\mathrm{HNO}_{3}, \mathrm{H}_{2} \mathrm{SO}_{4}$, and $\mathrm{HCIO}_{4}$ in 5:1:1 ratio (total $15 \mathrm{ml}$ ) using USEPA 3052 method. The digested sample further analyzed in ICP-OES for the heavy metal estimation.

\subsection{Bio-Concentration Factor (BCF)}

BCF index is an approach to determine the accumulation of particular metal in vegetable with respect to its concentration in soil substrate. It was calculated using the formula 


$$
B C F=\frac{C_{\text {plant }}}{C_{\text {soil }}}
$$

where $C_{\text {plant }}$ and $C_{\text {soil }}$ represent the heavy metal concentration in edible part of vegetables and soils, respectively [10].

\subsection{Health Risk Assessment}

Health risk assessment was performed using USEPA model [11], it estimate risk related to the exposure of heavy metal contamination via ingestion pathway in both adult and children. Hazard quotient (HQ) is the ratio of estimated concentration of pollutant to the reference dose, it also indicates the non-carcinogenic. If the value of $\mathrm{HQ}<1$, it is supposed there is no significant risk of non-carcinogenic effects. If the HQ $>1$ considerable health risk can be anticipated.

$$
\begin{gathered}
\mathrm{EDI}=\mathrm{C} \times \mathrm{DI} / \mathrm{BW} \\
\mathrm{HQ}=\mathrm{EDI} \times \mathrm{EF} \times \mathrm{ED} / \mathrm{RfD} \times \mathrm{AT}
\end{gathered}
$$

in this study, Daily intake (DI) for adult is $0.345 \mathrm{~kg} / \mathrm{person} /$ day and for children is $0.232 \mathrm{~kg} /$ person/day [12] $15 \mathrm{~kg}$ for children and $70 \mathrm{~kg}$ for adults, HQ is the Hazard Quotient, EF is the Exposure Frequency (350 days), ED is the Exposure Duration (70 years), RfD values of different metals were taken from the USEPA guidelines [13] and AT is the Average Time $(70 \times 365$ years) [10].

\section{Result and Discussion}

\subsection{Physiochemical Characteristics and Heavy Metal Status in the Soil}

The basic physiochemical characteristics of the agriculture soil are shown in the Table 1. The soil $\mathrm{pH}$ was observed to be near neutral to slightly alkaline with

Table 1. Physiochemical characteristics of the agriculture soil in the study area.

\begin{tabular}{cc}
\hline $\mathrm{pH}$ & $7.5 \pm 0.5$ \\
Sand (\%) & $52.0 \pm 11.4$ \\
Silt (\%) & $35.22 \pm 7.56$ \\
Clay (\%) & $12.8 \pm 1.82$ \\
Moisture (\%) & $56.10 \pm 3.81$ \\
OM (\%) & $5.36 \pm 1.02$ \\
TN $\left(\mathrm{mgkg}^{-1}\right)$ & $103.53 \pm 6.14$ \\
Sulfate $\left(\mathrm{mgkg}^{-1}\right)$ & $157.24 \pm 7.58$ \\
Phosphate $\left(\mathrm{mgkg}^{-1}\right)$ & $701.04 \pm 16.58$ \\
Potassium $\left(\mathrm{mgkg}^{-1}\right)$ & $153.0 \pm 8.6$ \\
Chloride $\left(\mathrm{mgkg}^{-1}\right)$ & $1014.0 \pm 36.65$ \\
EC $\left(\mathrm{mScm}^{-1}\right)$ & $2.49 \pm 0.02$ \\
\hline
\end{tabular}


$56.10 \%$ and $5.36 \%$ of mean moisture content and organic matter respectively. High phosphate and chloride content in the soil may result due to long-term wastewater irrigation. The mean conductivity was observed to be $2.49 \mathrm{mScm}^{-1}$ considering the fact that presence of ions and metals enhances the overall soil conductivity of the soil. The mean concentration of $\mathrm{Cd}, \mathrm{Cu}, \mathrm{Cr}, \mathrm{Pb}, \mathrm{Ni}$ and $\mathrm{Zn}$ were observed to be $1.65 \pm 0.65,35.82 \pm 20.18,60.70 \pm 40.91,30.76 \pm 13.05$, $89.63 \pm 53.62$ and $90.02 \pm 36.65 \mathrm{mg} / \mathrm{kg}$ respectively.

\subsection{Metal Concentration in Plant}

The mean metal concentration in the edible parts of samples vegetables are shown in the Figures 2(a)-(f). The metal concentrations were compared with the permissible safe limits prescribed by the Indian Standard [14] and World Health Organization (WHO)/Food and Agricultural Organization (FAO) [15]. Permissible limits of metals in food $(\mathrm{mg} / \mathrm{kg})$ as per Indian Standards are: $\mathrm{Cd}$ (1.5), $\mathrm{Cu}$ (30.0), $\mathrm{Cr}$ (20.0), $\mathrm{Pb}$ (2.5), Ni (1.5), Zn (50.0), and while WHO/FAO (2007) safe limits are: $\mathrm{Cd}(0.2), \mathrm{Cu}(40.0), \mathrm{Cr}(0.1) \mathrm{Pb}$ (5.0), and $\mathrm{Zn}(60.0)$. There is considerable difference in both the permissible limits; the concentration of $\mathrm{Cd}$ in Spinach, cabbage and radish were observed to be higher than the Indian permissible limit whereas, only Carrot (0.01) and Rice grain (0.01) samples were found to be under the permissible limit of WHO/FAO. $\mathrm{Cu}$ concentration in the sampled vegetables were high in Spinach (42.6), mustard (95.4) and cabbage (42.5), rest of the samples were in the permissible range. $\mathrm{Cr}$ concentration was observed highest in the cabbage (56.24) followed by sugarcane, mustard and radish. $\mathrm{Pb}$ concentration in mustard (56.24) was observed several folds higher than both Indian and WHO/FAO permissible limit followed by spinach, tomato and radish. $\mathrm{Ni}$ and $\mathrm{Zn}$ concentration were found highest in the mustard (114.6 and 756.43 respectively). Ni concentration in all the sampled vegetables was above the permissible limit.

Elevated concentrations of $\mathrm{Cd}, \mathrm{Cr}$ and $\mathrm{Pb}$ more than permissible limit is a serious concern in the study area as these metals are potent carcinogens and may lead to several diseases including cardiovascular, blood, kidney, and nervous system as well as diseases related with bone and muscles [2] [15]. The sources of these metals are mainly anthropogenic in origin which may include industrial and domestic waste, atmospheric deposition, vehicular emission etc. The study area comprises of large-scale industries including paper industry, distillery and sugar mill which is supposed to contribute significantly in the overall metal contamination in the study area. Paper mill generated wastewater contain significant concentration of $\mathrm{Cr}$ due to extensive use of Chromium based chemicals for different process involved in the manufacturing of paper [10] [16] [17]. The bioaccumulation potential of $\mathrm{Ni}$ is still under the study but $\mathrm{Ni}$ has significant toxic impact on the human being and considered as potent carcinogen. Zinc is an essential trace element for the growth of plants and animals, but excessive concentration may reduce the beneficial microbial activity and cause toxic effect [18]. 

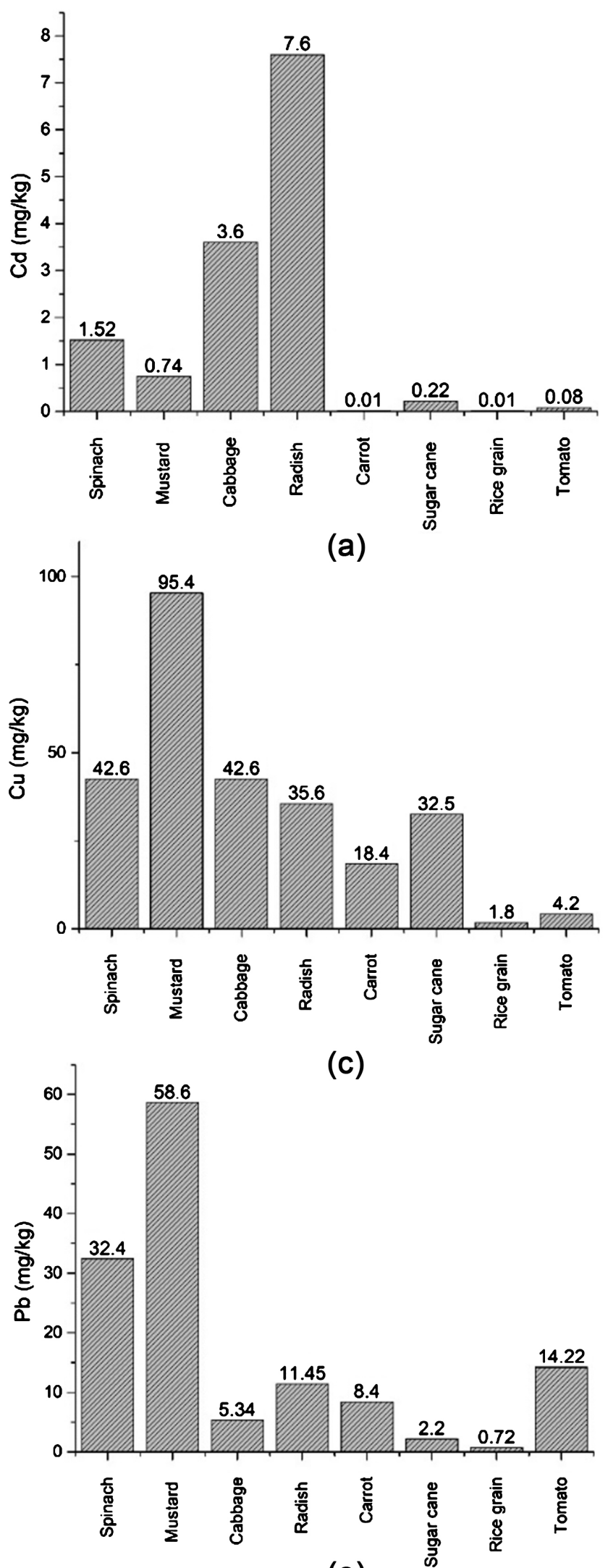

(e)
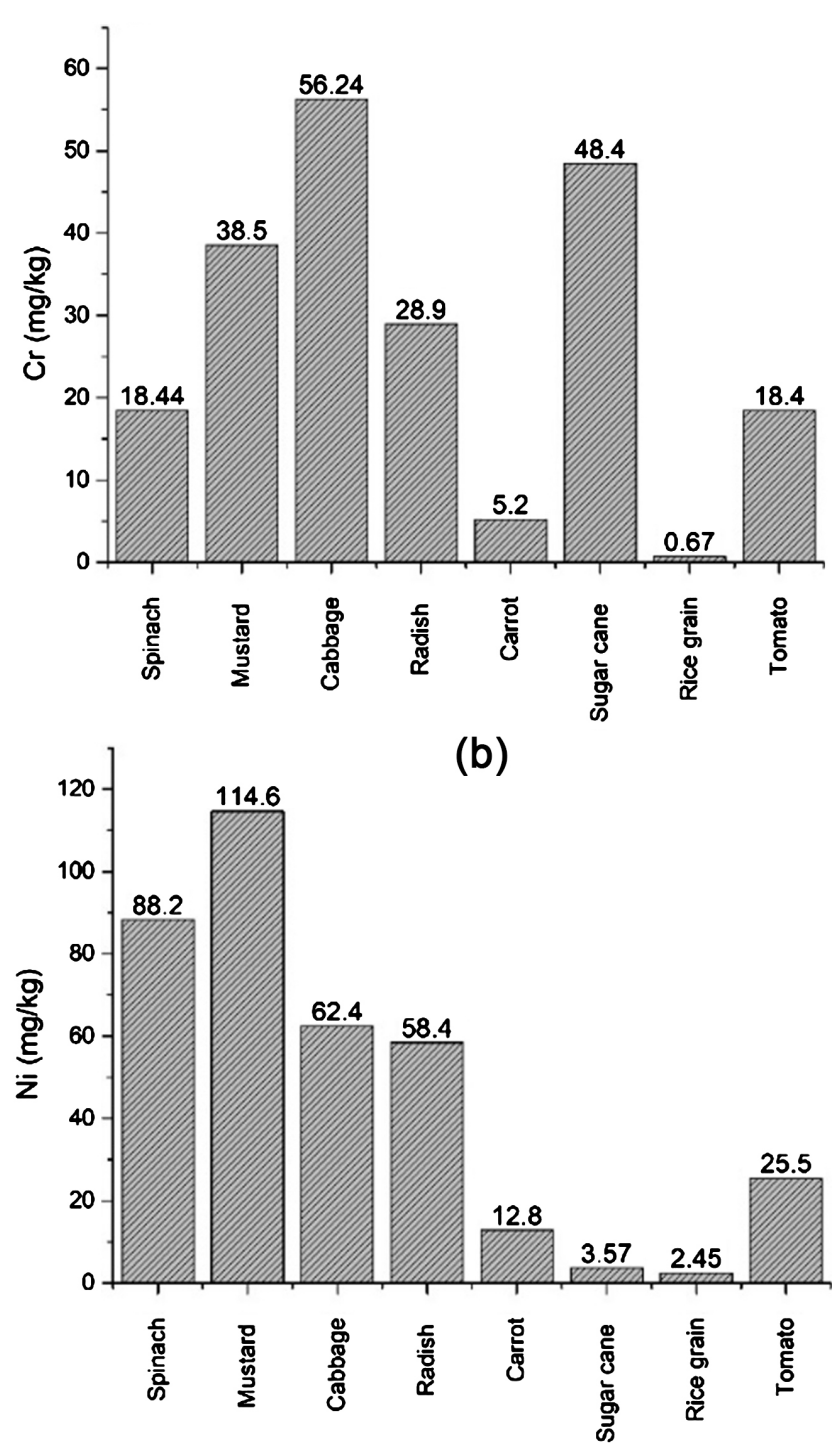

(d)

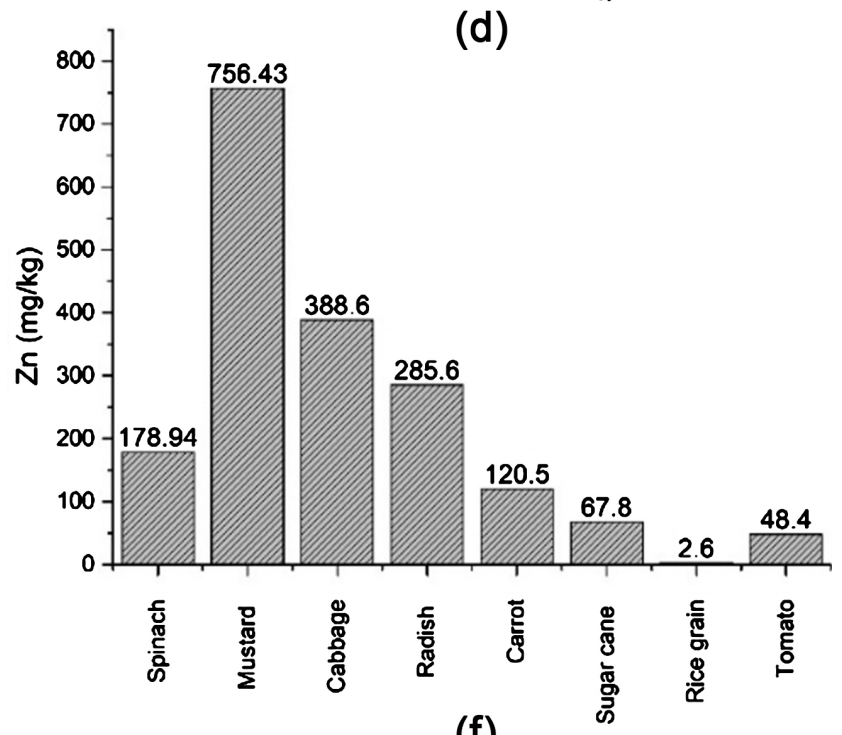

(f)

Figure 2. Metal concentrations in the vegetable samples procured from the study area. 


\subsection{Estimation of Bio-Concentration Factor and Average Daily Intake (ADI)}

The soil-plant transfer factor was estimated and wide range of transfer values were observed. High transfer factor was observed in spinach for all the metals except $\mathrm{Cr}$ (Figures 3(a)-(f)). BCF of Cd was significantly high in the Radish and cabbage. Mustard is an important crop, both leaves and oil seeds are used by the people; a very high $\mathrm{BCF}$ value of $\mathrm{Zn}$ (8.13) followed by $\mathrm{Cu}(2.66), \mathrm{Pb}(1.91)$ and $\mathrm{Ni}$ (1.28) was observed in the mustard plant. Leafy structure of cabbage may lead to accumulate metals significantly thus found to have considerably high BCF values for all the metals except $\mathrm{Pb}$. the minimum transfer factor value was observed in the Rice grains followed by tomato and carrot (Table 2).

\subsection{Health Risk Assessment in the Population}

The maximum daily intake of $\mathrm{Cd}$ was observed to be higher through the consumption of radish (3.05E-03) and cabbage (1.45E-03) followed by spinach and mustard. Among all the sampled vegetables maximum intake of $\mathrm{Cu}, \mathrm{Pb}$ and $\mathrm{Ni}$ was observed through the intake of mustard. Both leaf and oil seed of mustard is extensively consumed in the India, that may lead to the high exposure of these metals via food. The detailed data of EDI both in adult and children population is shown in the Table 3(a) \& Table 3(b).
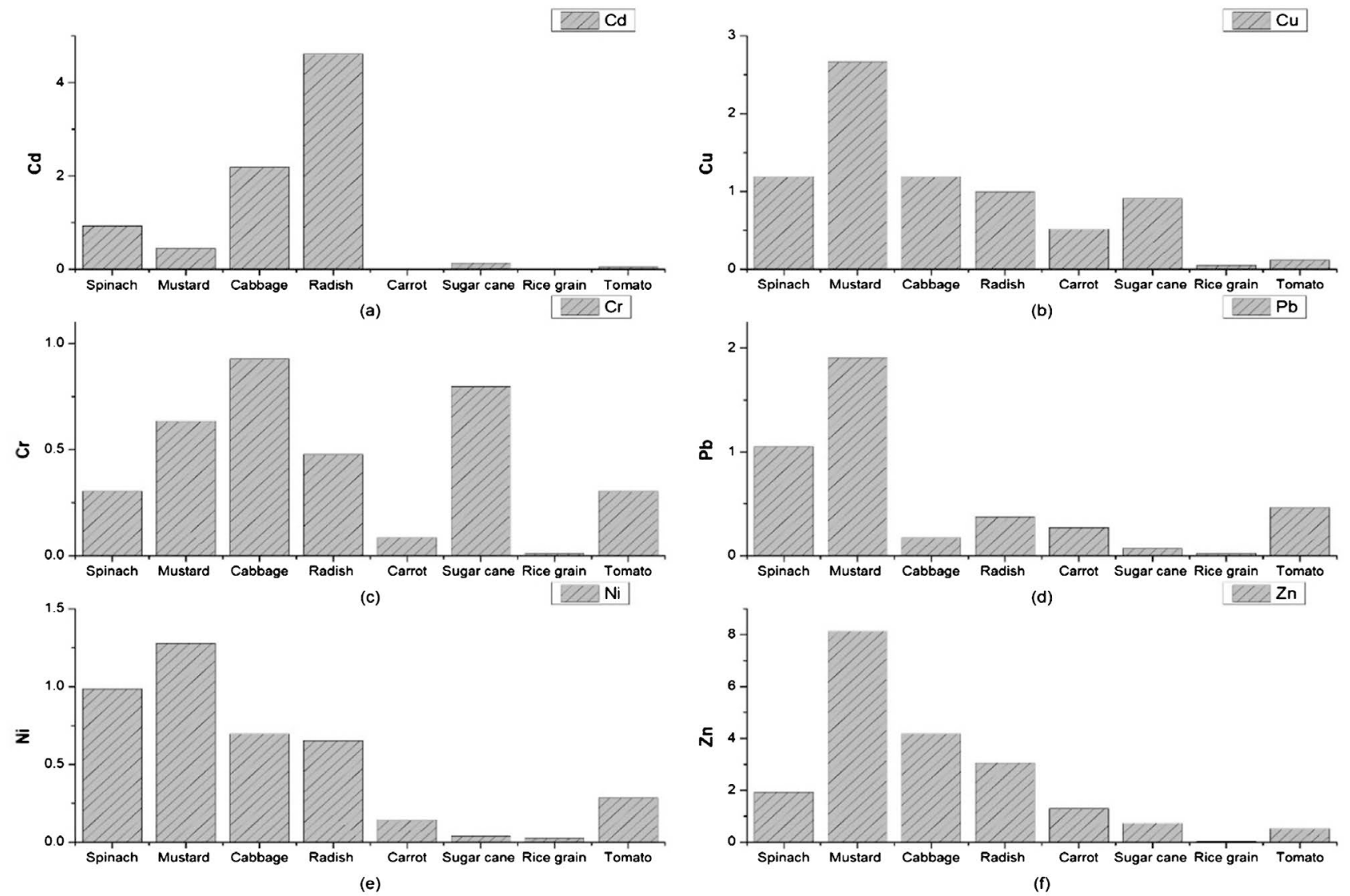

Figure 3. Estimation of Bio-concentration Factor in different vegetables. 
Table 2. Concentration of heavy metal $(\mathrm{mg} / \mathrm{kg})$ in the plant sample and permissible limit.

\begin{tabular}{ccccccc}
\hline Vegetable & $\mathrm{Cd}$ & $\mathrm{Cu}$ & $\mathrm{Cr}$ & $\mathrm{Pb}$ & $\mathrm{Ni}$ & $\mathrm{Zn}$ \\
\hline Spinach & 0.92 & 1.19 & 0.30 & 1.05 & 0.98 & 1.92 \\
Mustard & 0.45 & 2.66 & 0.63 & 1.91 & 1.28 & 8.13 \\
Cabbage & 2.18 & 1.19 & 0.93 & 0.17 & 0.70 & 4.18 \\
Radish & 4.61 & 0.99 & 0.48 & 0.37 & 0.65 & 3.07 \\
Carrot & 0.01 & 0.51 & 0.09 & 0.27 & 0.14 & 1.30 \\
Sugar cane & 0.13 & 0.91 & 0.80 & 0.07 & 0.04 & 0.73 \\
Rice grain & 0.01 & 0.05 & 0.01 & 0.02 & 0.03 & 0.03 \\
Tomato & 0.05 & 0.12 & 0.30 & 0.46 & 0.28 & 0.52 \\
Indian standard & 1.5 & 30.0 & 20.0 & 2.5 & 1.5 & 50.0 \\
WHO/FAO & 0.2 & 40.0 & 0.1 & 5.0 & -- & 60.0 \\
\hline
\end{tabular}

Table 3. (a) Estimated daily in-take (mg) of metal through vegetables in Adult population; (b) Estimated daily in-take (mg) of metal through vegetables in children population.

(a)

\begin{tabular}{ccccccc}
\hline \multirow{2}{*}{ Vegetable } & \multicolumn{5}{c}{ ADULT } \\
\cline { 2 - 7 } & $\mathrm{Cd}$ & $\mathrm{Cu}$ & $\mathrm{Cr}$ & $\mathrm{Pb}$ & $\mathrm{Ni}$ & $\mathrm{Zn}$ \\
\hline Spinach & $6.11 \mathrm{E}-04$ & $1.71 \mathrm{E}-02$ & $7.41 \mathrm{E}-03$ & $1.30 \mathrm{E}-02$ & $3.54 \mathrm{E}-02$ & $7.19 \mathrm{E}-02$ \\
Mustard & $2.97 \mathrm{E}-04$ & $3.83 \mathrm{E}-02$ & $1.55 \mathrm{E}-02$ & $2.35 \mathrm{E}-02$ & $4.60 \mathrm{E}-02$ & $3.04 \mathrm{E}-01$ \\
Cabbage & $1.45 \mathrm{E}-03$ & $1.71 \mathrm{E}-02$ & $2.26 \mathrm{E}-02$ & $2.15 \mathrm{E}-03$ & $2.51 \mathrm{E}-02$ & $1.56 \mathrm{E}-01$ \\
Radish & $3.05 \mathrm{E}-03$ & $1.43 \mathrm{E}-02$ & $1.16 \mathrm{E}-02$ & $4.60 \mathrm{E}-03$ & $2.35 \mathrm{E}-02$ & $1.15 \mathrm{E}-01$ \\
Carrot & $4.02 \mathrm{E}-06$ & $7.39 \mathrm{E}-03$ & $2.09 \mathrm{E}-03$ & $3.37 \mathrm{E}-03$ & $5.14 \mathrm{E}-03$ & $4.84 \mathrm{E}-02$ \\
Sugar cane stem & $8.84 \mathrm{E}-05$ & $1.31 \mathrm{E}-02$ & $1.94 \mathrm{E}-02$ & $8.84 \mathrm{E}-04$ & $1.43 \mathrm{E}-03$ & $2.72 \mathrm{E}-02$ \\
Rice grain & $4.02 \mathrm{E}-06$ & $7.23 \mathrm{E}-04$ & $2.69 \mathrm{E}-04$ & $2.89 \mathrm{E}-04$ & $9.84 \mathrm{E}-04$ & $1.04 \mathrm{E}-03$ \\
Tomato & $3.21 \mathrm{E}-05$ & $1.69 \mathrm{E}-03$ & $7.39 \mathrm{E}-03$ & $5.71 \mathrm{E}-03$ & $1.02 \mathrm{E}-02$ & $1.94 \mathrm{E}-02$ \\
\hline
\end{tabular}

(b)

\begin{tabular}{ccccccc}
\hline \multirow{2}{*}{ Vegetable } & \multicolumn{5}{c}{ CHILDREN } \\
\cline { 2 - 7 } & $\mathrm{Cd}$ & $\mathrm{Cu}$ & $\mathrm{Cr}$ & $\mathrm{Pb}$ & $\mathrm{Ni}$ & $\mathrm{Zn}$ \\
\hline Spinach & $1.82 \mathrm{E}-03$ & $5.11 \mathrm{E}-02$ & $2.21 \mathrm{E}-02$ & $3.89 \mathrm{E}-02$ & $1.06 \mathrm{E}-01$ & $2.15 \mathrm{E}-01$ \\
Mustard & $8.88 \mathrm{E}-04$ & $1.14 \mathrm{E}-01$ & $4.62 \mathrm{E}-02$ & $7.03 \mathrm{E}-02$ & $1.38 \mathrm{E}-01$ & $9.08 \mathrm{E}-01$ \\
Cabbage & $4.32 \mathrm{E}-03$ & $5.11 \mathrm{E}-02$ & $6.75 \mathrm{E}-02$ & $6.41 \mathrm{E}-03$ & $7.49 \mathrm{E}-02$ & $4.66 \mathrm{E}-01$ \\
Radish & $9.12 \mathrm{E}-03$ & $4.27 \mathrm{E}-02$ & $3.47 \mathrm{E}-02$ & $1.37 \mathrm{E}-02$ & $7.01 \mathrm{E}-02$ & $3.43 \mathrm{E}-01$ \\
Carrot & $1.20 \mathrm{E}-05$ & $2.21 \mathrm{E}-02$ & $6.24 \mathrm{E}-03$ & $1.01 \mathrm{E}-02$ & $1.54 \mathrm{E}-02$ & $1.45 \mathrm{E}-01$ \\
Sugar cane stem & $2.64 \mathrm{E}-04$ & $3.90 \mathrm{E}-02$ & $5.81 \mathrm{E}-02$ & $2.64 \mathrm{E}-03$ & $4.28 \mathrm{E}-03$ & $8.14 \mathrm{E}-02$ \\
Rice grain & $1.20 \mathrm{E}-05$ & $2.16 \mathrm{E}-03$ & $8.04 \mathrm{E}-04$ & $8.64 \mathrm{E}-04$ & $2.94 \mathrm{E}-03$ & $3.12 \mathrm{E}-03$ \\
Tomato & $9.60 \mathrm{E}-05$ & $5.04 \mathrm{E}-03$ & $2.21 \mathrm{E}-02$ & $1.71 \mathrm{E}-02$ & $3.06 \mathrm{E}-02$ & $5.81 \mathrm{E}-02$ \\
\hline
\end{tabular}


The Hazard quotient also referred as non-carcinogenic risk was estimated in both adult and children population and depicted in Table 4(a) and Table 4(b). Children population were observed to be more susceptible to the risk associated with metal exposure through intake of vegetables. Risk associated with $\mathrm{Cd}$ was found to be maximum via consumption of Radish cabbage and spinach in both adult and children population. The leafy vegetables including spinach, cabbage, mustard leaves showing high health risk probability of metal exposure through consumption as they receive high amount of atmospheric depositions, vehicular and industrial dust when grown in peri urban areas and could absorb heavy metals due to their large foliar surface area [19]. For the reason health risk associated with consumption of Spinach, cabbage, Mustard along with root or tuberous vegetable were observed to be considerably high in comparison to the tomato, sugarcane and rice grains. Health risk index associated with Ni exposure through consumption of spinach, mustard, cabbage and radish were observed to

Table 4. (a) Health risk or Hazard quotient (HQ) in the adult population in the study area; (b) Health risk or Hazard quotient (HQ) in the children population in the study area.

(a)

\begin{tabular}{ccccccc}
\hline \multirow{2}{*}{ Vegetable } & \multicolumn{5}{c}{ ADULT } \\
\cline { 2 - 7 } & $\mathrm{Cd}$ & $\mathrm{Cu}$ & $\mathrm{Cr}$ & $\mathrm{Pb}$ & $\mathrm{Ni}$ & $\mathrm{Zn}$ \\
\hline Spinach & $6.11 \mathrm{E}-01$ & $4.28 \mathrm{E}-01$ & $4.94 \mathrm{E}-03$ & $3.25 \mathrm{E}+00$ & $1.77 \mathrm{E}+00$ & $2.40 \mathrm{E}-01$ \\
Mustard & $2.97 \mathrm{E}-01$ & $9.58 \mathrm{E}-01$ & $1.03 \mathrm{E}-02$ & $5.88 \mathrm{E}+00$ & $2.30 \mathrm{E}+00$ & $1.01 \mathrm{E}+00$ \\
Cabbage & $1.45 \mathrm{E}+00$ & $4.28 \mathrm{E}-01$ & $1.51 \mathrm{E}-02$ & $5.36 \mathrm{E}-01$ & $1.25 \mathrm{E}+00$ & $5.20 \mathrm{E}-01$ \\
Radish & $3.05 \mathrm{E}+00$ & $3.58 \mathrm{E}-01$ & $7.74 \mathrm{E}-03$ & $1.15 \mathrm{E}+00$ & $1.17 \mathrm{E}+00$ & $3.82 \mathrm{E}-01$ \\
Carrot & $4.02 \mathrm{E}-03$ & $1.85 \mathrm{E}-01$ & $1.39 \mathrm{E}-03$ & $8.44 \mathrm{E}-01$ & $2.57 \mathrm{E}-01$ & $1.61 \mathrm{E}-01$ \\
Sugar cane stem & $8.84 \mathrm{E}-02$ & $3.26 \mathrm{E}-01$ & $1.30 \mathrm{E}-02$ & $2.21 \mathrm{E}-01$ & $7.17 \mathrm{E}-02$ & $9.08 \mathrm{E}-02$ \\
Rice grain & $4.02 \mathrm{E}-03$ & $1.81 \mathrm{E}-02$ & $1.79 \mathrm{E}-04$ & $7.23 \mathrm{E}-02$ & $4.92 \mathrm{E}-02$ & $3.48 \mathrm{E}-03$ \\
Tomato & $3.21 \mathrm{E}-02$ & $4.22 \mathrm{E}-02$ & $4.93 \mathrm{E}-03$ & $1.43 \mathrm{E}+00$ & $5.12 \mathrm{E}-01$ & $6.48 \mathrm{E}-02$ \\
\hline
\end{tabular}

(b)

\begin{tabular}{ccccccc}
\hline \multirow{2}{*}{ Vegetable } & \multicolumn{5}{c}{ CHILDREN } \\
\cline { 2 - 7 } & $\mathrm{Cd}$ & $\mathrm{Cu}$ & $\mathrm{Cr}$ & $\mathrm{Pb}$ & $\mathrm{Ni}$ & $\mathrm{Zn}$ \\
\hline Spinach & $1.82 \mathrm{E}+00$ & $1.28 \mathrm{E}+00$ & $1.48 \mathrm{E}-02$ & $9.72 \mathrm{E}+00$ & $5.29 \mathrm{E}+00$ & $7.16 \mathrm{E}-01$ \\
Mustard & $8.88 \mathrm{E}-01$ & $2.86 \mathrm{E}+00$ & $3.08 \mathrm{E}-02$ & $1.76 \mathrm{E}+01$ & $6.88 \mathrm{E}+00$ & $3.03 \mathrm{E}+00$ \\
Cabbage & $4.32 \mathrm{E}+00$ & $1.28 \mathrm{E}+00$ & $4.50 \mathrm{E}-02$ & $1.60 \mathrm{E}+00$ & $3.74 \mathrm{E}+00$ & $1.55 \mathrm{E}+00$ \\
Radish & $9.12 \mathrm{E}+00$ & $1.07 \mathrm{E}+00$ & $2.31 \mathrm{E}-02$ & $3.44 \mathrm{E}+00$ & $3.50 \mathrm{E}+00$ & $1.14 \mathrm{E}+00$ \\
Carrot & $1.20 \mathrm{E}-02$ & $5.52 \mathrm{E}-01$ & $4.16 \mathrm{E}-03$ & $2.52 \mathrm{E}+00$ & $7.68 \mathrm{E}-01$ & $4.82 \mathrm{E}-01$ \\
Sugar cane stem & $2.64 \mathrm{E}-01$ & $9.75 \mathrm{E}-01$ & $3.87 \mathrm{E}-02$ & $6.60 \mathrm{E}-01$ & $2.14 \mathrm{E}-01$ & $2.71 \mathrm{E}-01$ \\
Rice grain & $1.20 \mathrm{E}-02$ & $5.40 \mathrm{E}-02$ & $1.44 \mathrm{E}-03$ & $2.16 \mathrm{E}-01$ & $1.47 \mathrm{E}-01$ & $1.04 \mathrm{E}-02$ \\
Tomato & $9.60 \mathrm{E}-02$ & $1.26 \mathrm{E}-01$ & $3.36 \mathrm{E}-03$ & $4.27 \mathrm{E}+00$ & $1.53 \mathrm{E}+00$ & $1.94 \mathrm{E}-01$ \\
\hline
\end{tabular}


be higher than the threshold value $(\mathrm{HQ}>1)$ signifying considerable health risk in both adult and children population. Sugarcane is the extensively grown throughout the study area; the exposure of metal through sugarcane consumption was found to be under the permissible range for adult population but was observed to be closer to the threshold value in children population. Rice is the staple food crop in the India, although the concentration of metal and risk associated with it was observed to be low but daily consumption may lead to pronounced dietary intake of metal.

\section{Conclusion}

The present study revealed the status of metal contamination in the vegetables grown in the upper most Ganga-Yamuna Doab region of India and associated health risk. Metals concentration in leafy/tuberous vegetables was observed higher than other vegetables. The metal concentration in almost all plant samples was found to be beyond or close to the permissible limit. The overall bio-concentration factor or transfer factor from soil to plant was observed in the trend $\mathrm{Zn}>\mathrm{Cd}>\mathrm{Cu}>\mathrm{Pb}>\mathrm{Ni}>\mathrm{Cu}$. Health risk assessment revealed considerable health risk for $\mathrm{Cd}, \mathrm{Pb}$ and $\mathrm{Ni}$ metals. $\mathrm{HQ}$ index for $\mathrm{Cu}$ and $\mathrm{Zn}$ was observed to be close or beyond the safe limit but had considerably low toxic impact in comparison to other studied metals. The results of the present work suggest precise monitoring of metals contamination in agricultural soils and in vegetables as well. So that excessive input of metals in human food chain system can be checked.

\section{Acknowledgements}

The author would like to acknowledge Central Instrumentation Facility, IIT Roorkee (Saharanpur Campus) for providing analytical facilities and MHRD contingency for the financial support.

\section{Conflicts of Interest}

The authors declare no conflicts of interest regarding the publication of this paper.

\section{References}

[1] Zheng, N., Wang, Q., Zhang, X., Zheng, D., Zhang, Z. and Zhang, S. (2007) Population Health Risk Due to Dietary Intake of Heavy Metals in the Industrial Area of Huludao City, China. Science of the Total Environment, 387, 96-104. https://doi.org/10.1016/j.scitotenv.2007.07.044

[2] Chabukdhara, M., Munjal, A., Nema, A.K., Gupta, S.K. and Kaushal, R. (2015) Heavy Metal Contamination in Vegetables Grown around Peri-Urban and Urban-Industrial Clusters in Ghaziabad, India. Human and Ecological Risk Assessment: An International Journal, 22, 736-752. https://doi.org/10.1080/10807039.2015.1105723

[3] Singh, R.P. and Agrawal, M. (2010) Variations in Heavy Metal Accumulation, 
Growth and Yield of Rice Plants Grown at Different Sewage Sludge Amendment Rates. Ecotoxicology and Environmental Safety, 73, 632-641. https://doi.org/10.1016/j.ecoenv.2010.01.020

[4] Kumar, M., Ramanathan, A., Tripathi, R., Farswan, S., Kumar, D. and Bhattacharya, P. (2017) A Study of Trace Element Contamination Using Multivariate Statistical Techniques and Health Risk Assessment in Groundwater of Chhaprola Industrial Area, Gautam Buddha Nagar, Uttar Pradesh, India. Chemosphere, 166, 135-145. https://doi.org/10.1016/j.chemosphere.2016.09.086

[5] Liu, J., Duan, C.Q., Zhu, Y.N., Zhang, X.H. and Wang, C.X. (2007) Effect of Chemical Fertilizers on the Fractionation of $\mathrm{Cu}, \mathrm{Cr}$ and $\mathrm{Ni}$ in Contaminated Soil. Environmental Geology, 52, 1601-1606. https://doi.org/10.1007/s00254-006-0604-7

[6] Pandey, R., Shubhashish, K. and Pandey, J. (2012) Dietary Intake of Pollutant Aerosols via Vegetables Influenced by Atmospheric Deposition and Wastewater Irrigation. Ecotoxicology and Environmental Safety, 76, 200-208.

https://doi.org/10.1016/j.ecoenv.2011.10.004

[7] Ministry of MSME (2015) Brief Industrial Profile of District Saharanpur. 1-18.

[8] Agrawal, P., Mittal, A., Prakash, R., Kumar, M., Singh, T.B. and Tripathi, S.K. (2010) Assessment of Contamination of Soil Due to Heavy Metals around Coal Fired Thermal Power Plants at Singrauli Region of India. Bulletin of Environmental Contamination and Toxicology, 85, 219-223. https://doi.org/10.1007/s00128-010-0043-8

[9] USEPA (1996) Microwave Assisted Acid Digestion of Siliceous and Organically Based Matrices.

[10] Pandey, B., Suthar, S. and Singh, V. (2016) Accumulation and Health Risk of Heavy Metals in Sugarcane Irrigated with Industrial Effluent in Some Rural Areas of Uttarakhand, India. Process Safety and Environmental Protection, 102, 655-666. https://doi.org/10.1016/j.psep.2016.05.024

[11] USEPA-U.S. (2005) Environmental Protection Agency. Guidelines for Carcinogen Risk Assessment. Risk Assessment Forum, 630, 22-58.

[12] Arora, M., Kiran, B., Rani, S., Rani, A., Kaur, B. and Mittal, N. (2008) Heavy Metal Accumulation in Vegetables Irrigated with Water from Different Sources. Food Chemistry, 111, 811-815. https://doi.org/10.1016/j.foodchem.2008.04.049

[13] USEPA-IRISD (1993) Reference Dose (RfD): Description and Use in Health Risk Assessments.

[14] Awasthi, S.K. (2000) Prevention of Food Adulteration Act (Act No. 37 of 1954), Central and State Rules as Amended for 1999. 3rd Edition, Ashoka Law House, New Delhi.

[15] WHO/FAO (World Health Organization/Food and Agriculture Organization) (2007) Joint FAO/WHO Food Standards Programme Codex Alimentarius Commission Twenty-Seventh Session Report of the Thirty-Sixth Session of the Codex Committee on Food Hygiene.

[16] Fazeli, M.S., Khosravan, F., Hossini, M., Sathyanarayan, S. and Satish, P.N. (1998) Enrichment of Heavy Metals in Paddy Crops Irrigated by Paper Mill Effluents Near Nanjangud, Mysore District, Karnatake, India. Environmental Geology, 34, 297-302. https://doi.org/10.1007/s002540050281

[17] Chhonkar, P.K., Datta, S.P., Loshi, H.C. and Pathak, H. (2000) Impact of Industrial Effluents on Soil Health and Agriculture-Indian Experience: Part I-Distillery and Paper Mill Effluents. Journal of Scientific \& Industrial Research, 59, 350-361. 
[18] Nagajyoti, P.C., Lee, K.D. and Sreekanth, T.V.M. (2010) Heavy Metals, Occurrence and Toxicity for Plants: A Review. Environmental Chemistry Letters, 8, 199-216. https://doi.org/10.1007/s10311-010-0297-8

[19] Pandey, J., Pandey, R. and Shubhashish, K. (2009) Air-Borne Heavy Metal Contamination to Dietary Vegetables: A Case Study from India. Bulletin of Environmental Contamination and Toxicology, 83, 931-936.

https://doi.org/10.1007/s00128-009-9879-1 